\title{
Quality and Viability of Javanese Local Ram Semen at Different Age
}

\author{
Solihati N, Rasad SD, Setiawan R, Alvionita C \\ Faculty of Animal Science, Padjadjaran University \\ Sumedang 45363, West Java, Indonesia \\ nurcholidah@yahoo.com
}

\begin{abstract}
Age is one of determinant factors on semen quality due to its relation with the development of male's reproductive tracts. Therefore, the objective of this study was to observe semen quality and viability at different level of ages in Javanese local sheep. The method used in this study was Complete Randomized Design with five groups of treatment consisted of groups of sheep aged: under 12 months (G1), 12-24 months (G2), 25-36 months (G3), 37-48 months (G4), and 49-72 months (G5). Each group consisted of four rams as replication and each replication was evaluated four times. Data collective which analyzed descriptively were: semen color, odor, viscosity, $\mathrm{pH}$, sperm viability. While data on semen volume, sperm concentration, and sperm abnormality were analyzed using analysis of variance followed by Duncan's multiple range test for the differences among treatments. The result showed that no significant different found for semen quality parameters at different ages of $\operatorname{ram}(\mathrm{P}>0.05)$, except for sperm motility $(\mathrm{P}<0.05)$. The lowest sperm motility $(70.62 \%)$ found in G1 and significantly differs from other groups. The lowest sperm viability was also found in G1 after the chilled semen was kept for 4 to 5 days at $40 \%$ of motility, while the highest viability was in G3 by 9 days for $43.75 \%$ of motility. In conclusion: (1) Sperm motility of local ram semen was influenced by age; (2) Ram aged 25-36 months produces the highest motility of sperm and viability.
\end{abstract}

Key Words: Semen Quality, Sperm Viability, Age, Local Ram

\section{INTRODUCTION}

Age of livestock is one of the easiest parameters in breeding selection program of ram for semen quality. This parameter is correlated with scrotal circumference thus by increasing the ability of tubulus seminiferous in sperm production. At puberty, ram tends to have lower semen quality, but in increased along with the increasing of age however the semen quality decreased in older ram.

Age and scrotal circumference is positively correlated with semen production and total sperm concentration (Nataatmaja \& Arifin 2008). Ram aged 1-2 years is an optimum stage in the development of testicular size. At this stage, the average development of testicular circumference and testicular size reach maximum change by 1.68 and $0.79 \mathrm{~cm}$, respectively. The development decrease when the ram aged $2-3$ years by $0.68 \mathrm{~cm}$ of testicular circumference and $0.64 \mathrm{~cm}$ of testicular length. The slight increase of testicular size in ram at three years age showed that the development of the testes decreased (Koyuncu et al. 2005).

Feradis (2010a) reported that the development of age related testicular size is affected by hormonal status in the body. Luteinizing Hormone (LH) increased significantly during puberty which leads to stimulate leydig cells and testosterone. This hormone is responsible for the production of sperm. However, the hormone decreased in old rams. Several publications elucidated that semen quality produced from ram aged 2-5 years higher that that produced from ram aged more than 8 years (Rizal et al. 2003; David et al. 2006; Sudarjat 2009). Information concerning age related semen quality of ram needs to be explored in more detail, especially in indigenous breed ram. Therefore, the aim of this 
study was focused on semen quality and sperm viability of Javanese local sheep at different level of age.

\section{MATERIAL AND METHODS}

This research used twenty Javanese local sheep's with five group of age, consisted of group of sheep aged under 12 months (G1); 12-24 months (G2); 25-36 months (G3); 37-48 months (G4); and 49-72 months (G5). Each group consisted of four replications. Semen collected from these five group was evaluated.

Semen was collected using artificial vagina (AV) and then was evaluated its semen quality. Semen viability was evaluated by making chilled semen and stored at $4-5^{\circ} \mathrm{C}$, and measured its motility until nine days.

This research use randomized complete design. The data observed were semen color, odor, viscosity, $\mathrm{pH}$, volume and sperm viability were descriptively analyzed. Whilst, sperm concentration, motility and sperm abnormality were analyzed using analysis of variance followed by Duncan's multiple range test for the differences among treatments (Gaspersz 2006).

\section{RESULTS AND DISCUSSION}

\section{Quality of Javanese local ram semen at different age}

Result of this study (Table 1) showed that semen volume of ram aged under one year old or at puberty tends to have slight semen in volume $(0.59 \mathrm{ml})$. This condition might be due to inexperienced of the ram during semen collection using artificial vagina which leads to low erection and ejaculation thus decreasing the volume (Toelihere 1993a).

Table 1. Quality of local ram semen at different age

\begin{tabular}{|c|c|c|c|c|c|}
\hline \multirow{2}{*}{ Parameters } & \multicolumn{5}{|c|}{ Age (month) } \\
\hline & $<12$ & $12-24$ & $25-36$ & $37-48$ & $49-72$ \\
\hline Color & $\begin{array}{l}\text { Creamy- } \\
\text { white }\end{array}$ & $\begin{array}{l}\text { Creamy- } \\
\text { white }\end{array}$ & $\begin{array}{l}\text { Creamy- } \\
\text { white }\end{array}$ & $\begin{array}{l}\text { Creamy- } \\
\text { white }\end{array}$ & $\begin{array}{l}\text { Creamy- } \\
\text { white }\end{array}$ \\
\hline Consistency & $\begin{array}{l}\text { Aquous- } \\
\text { Condensed }\end{array}$ & $\begin{array}{l}\text { Aquous- } \\
\text { Condensed }\end{array}$ & $\begin{array}{l}\text { Aquous- } \\
\text { Condensed }\end{array}$ & Condensed & Condensed \\
\hline Odor & Typical ram & Typical ram & Typical ram & Typical ram & Typical ram \\
\hline Volume (ml) & $0.59 \pm 0.20$ & $0.74 \pm 0.13$ & $0.73 \pm 0.17$ & $0.74 \pm 0.14$ & $0.60 \pm 0.28$ \\
\hline $\mathrm{pH}$ & $6.8 \pm 0.2$ & $6.6 \pm 0.1$ & $6.5 \pm 0.1$ & $6.5 \pm 0.1$ & $6.5 \pm 0.0$ \\
\hline $\begin{array}{l}\text { Total sperm } \\
\text { concentration } \\
\left(\times 10^{7} \text { cell } / \mathrm{ml}\right)\end{array}$ & $278.00 \pm 37.20$ & $307.88 \pm 49.02$ & $291.81 \pm 71.35$ & $299.50 \pm 32.76$ & $343.88 \pm 68.27$ \\
\hline Motility (\%) & $70.62 \pm 8.63^{\mathrm{a}}$ & $81.91 \pm 4.13^{b}$ & $87.21 \pm 0.81^{\mathrm{b}}$ & $81.74 \pm 2.80^{\mathrm{b}}$ & $81.30 \pm 8.69^{b}$ \\
\hline $\begin{array}{l}\text { Abnormality } \\
(\%)\end{array}$ & $3.26 \pm 1.34$ & $5.38 \pm 3.59$ & $3.10 \pm 1.91$ & $3.02 \pm 1.93$ & $4.05 \pm 2.29$ \\
\hline
\end{tabular}

A similar result with group 1 (G1), ram aged 49-72 months old ejaculates a low semen volume ( $0.6 \mathrm{ml} / \mathrm{ejaculate})$. Low semen volume is not disadvantage, but if it is accompanied by low concentrations would limit the number of spermatozoa availability (Feradis 2010b). According to Heriyanta et al. (2013), semen from old Buck tends to have less volume due 
to the decreasing of spermatogenetic activities. Lestari et al. (2013) reported that there was highly significant $(\mathrm{P}<0.01)$ correlation between age and semen volume. However, Herdis et al. (2005) added that in addition to age, semen volume affected by body condition, health, and frequency of semen collection.

Semen $\mathrm{pH}$ was measured using digital $\mathrm{pH}$ meter. The result showed that semen $\mathrm{pH}$ in this study ranged 6.5-6.8. This result is classified as a normal $\mathrm{pH}$ semen as stated by Garner \& Hafez (2000) that a normal pH semen ranged 6.4-7.8. Furthermore, Sujoko et al. (2009) elucidated that the lower the $\mathrm{pH}$ semen, the higher the death sperm. The variation of $\mathrm{pH}$ semen is controlled by semen plasm which is produced by accessories glands. The plasm serves as a buffer medium from the fluctuation of $\mathrm{pH}$ which could degrade and decrease sperm viability (Evans \& Maxwell 1987 in Sujoko et al. 2009).

According to the result from analysis of variance, there is no significant different on sperm concentration due to different ram age $(\mathrm{P}>0.05)$. However, the lowest sperm concentration was in puberty group. This might be due to hormonal level which control spermatogenesis. Heriyanta et al. (2013) reported that sperm concentration is affected by age and tends to increase until the ram age reach 22 months.

In this study, total sperm concentration ranged $278-343 \times 10^{7} \mathrm{cell} / \mathrm{ml}$ consistent with those findings reported by Toelihere (1993b) that a normal total sperm concentration of ram is about $200-600 \times 10^{7}$ and $200-300 \times 10^{7}$, respectively.

Reproductive system in puberty phase is under development, concomitant with the increasing of age that frequency of LH surge in puberty phase increased and related to the increasing of the size of reproductive organs (Feradis 2010). Moreover, Kheradmand et al. (2006) in Nataatmaja \& Arifin (2008) elucidated that total sperm concentration is highly positive correlated with scrotal circumference of ram.

Result from analysis of variance in this study showed that age was significantly $(\mathrm{P}<0.05)$ effect on sperm motility. The sperm motility $87.21 \%$ was in ram aged $25-36$ months old and the sperm motility $70.62 \%$ was in ram aged under 12 months old (70.62\%). Result from Duncan's test showed that aged $<12$ months have lowest sperm motility than all other group. This study according to a statement David et al. (2006), that lamb at 1-2 years has mature body weight where sheep can be mated, and sheep aged 2-3 years old are able to produce stable cement quality. Sudarjat (2009) reported that spermatozoa motility and concentration of sheep aged 2-3 years was higher than the age of the sheep older than eight years old. However, the lowest motility and concentration in this study is still classified as a normal motility of sperm (Garner \& Hafez 2000; Graham 1994 in Feradis 2007). According to Sarastina et al. (2012), motility and progressive motility can be improve through the sufficient provision of forage and produce semen similar to mature males. Kheradmand et al. (2006) stated that nutrition appears to mediate its effect through increasing the frequency release of LH and FSH. Several studies reported that spermatogenesis in rams is sensitive to increases in protein intake which related to the increasing of testicular size.

The average of abnormality of native rams in this study ranged 3.1-4.05\%. Analysis of variance showed that age did not significantly effect on sperm abnormality. This finding is inconsistent with those findings obtained by Riyadhi et al. (2012) who reported that older rams tend to have higher sperm abnormality because of the degeneration of body cells and reproductive organs.

According to Toelihere (1993a), sperm abnormality is influenced by human errors during semen collection, pathological disorders, contaminations, and semen processing. In this study, the type of sperm abnormality which was evaluated is primary abnormality of sperm, including double head, double tail, hairpin tail, giant head, and coiled tail. 


\section{Viability of Javanese local ram sperm at different age}

Sperm viability is the ability of spermatozoa to maintain their life in a certain time that can be measured based on its motility. In this study, sperm viability of chilled semen was evaluated at different age of ram. The result of this research showed that the best viability was found in semen from group of ram aged 25-36 months (Figure 1). The semen viability from this group at nine days had more than $40 \%$ of sperm motility. The lowest sperm viability belongs to the group of ram aged under 12 months.

During processing semen into chilled semen, sperm is exposed to oxygen which leads to the production of free radicals. These radicals accelerate metabolism rate and lipid peroxidation causing sperm plasm membrane damage and sperm death (Syarifuddin et al. 2012; Suryohudoyo 2000). Furthermore, Werdhany (1999) reported that the plasm membrane damage could relieve mitochondrial enzymes contained in the sperm which is used in sperm movement. Podstawski et al. (2007) stressed in their publications that some enzymes (aspartate aminotrahspherase, Lactate dehydrogenase, alkaline phosphatase, and total protein) increase in seminal plasma after sperm membrane damage. Moreover, the publication also elucidated that the activities of these enzymes decreased when the percent of sperms with cytoplasmic droplet increased. This could be a reason that semen in young age (puberty) has a poor quality of semen due to a high sperm with cytoplasmic droplet and a low activities of mitochondrial enzymatic of sperm.

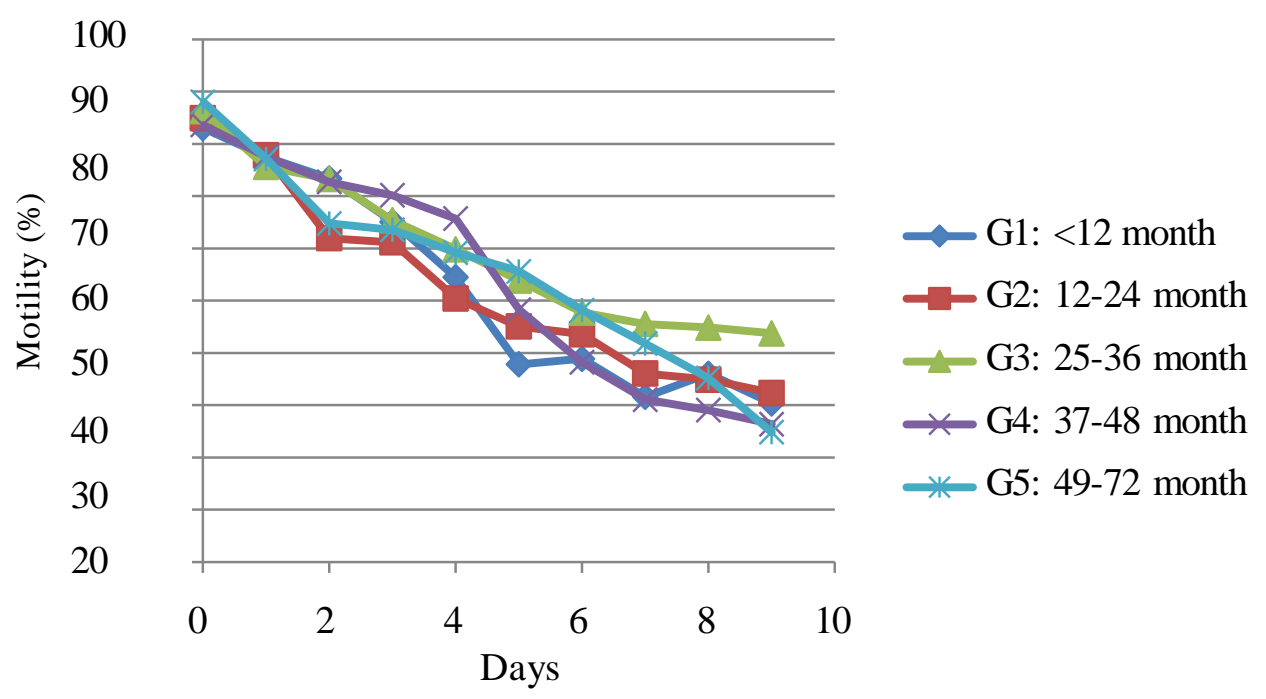

Figure 1. Viability of local ram at different age

\section{CONCLUSION}

From study can be concluded that sperm motility of local ram semen was influenced by age. Ram aged 25-36 months produces the highest motility of sperm and viability.

\section{ACKNOWLEDGEMENT}

This study was supported by research grant of Penelitian Unggulan Perguruan Tinggi (PUPT) University of Padjadjaran. 


\section{REFERENCES}

David I, Bodin L, Lagriffoul G, Manfredi E, Robert C, Granie. 2006. Character process model for semen volume in ai rams: Evaluation of correlation structures for long and short-term environmental effects. Genet Sel Evol. 39:55-71.

Feradis. 2007. Karakteristik sifat fisik semen domba St. Croix. Jurnal Petemakan. 4:51-69.

Feradis. 2010a. Reproduksi Ternak. Bandung (Indonesia): Alfabeta.

Feradis. 2010b. Bioteknologi Reproduksi Ternak. Bandung (Indonesia): Alfabeta.

Gaspersz V. 2006. Teknik Analisis dalam Penelitian Percobaan. Bandung (Indonesia): Tarsito. p. 62-84.

Heriyanta E, Ihsan MN, Isnaini N. 2013. Pengaruh umur kambing Peranakan Etawah (PE) terhadap kualitas semen segar. J Ternak Tropika. 14:1-5.

Herdis, Toelihere MR, Supriatna I, Purwantara B, Adikara RTS. 2005. Optimalisasi kualitas semen cair domba Garut (Ovis aries) melalui penambahan maltosa ke dalam pengencer semen tris kuning telur (optimization of Garut ram liquid semen quality by addition of maltose into the egg yolk tris extender). Media Kedokteran Hewan. 21:88-93.

Koyuncu M, Kara Uzun M, Ozis S, Duru S. 2005. Development of testicular dimensions and size, and their relationship to age and body weight in growing Kivircik (Western Thrace) ramlambs. Czech J Anim Sci. 50:243-248.

Lestari S, Saleh DM, Maidaswar. 2013. Profil kualitas semen segar sapi pejantan Limousin dengan umur yang berbeda di Balai Inseminasi Buatan Lembang Jawa Barat (Profile of fresh semen quality of Limousin bulls with different age in the Centre of artificial insemination in Lembang West Java). Jurnal Ilmiah Peternakan. 1:1165-1172.

Nataatmaja DM, Arifin J. 2008. Karakteristik ukuran tubuh dan reproduksi jantan pada kelompok populasi domba di Kabupaten Pandeglang dan Garut. Anim Prod. 10:140-146.

Podstawski Z, Kosiniak-Kamysz K, Bittmar A. 2007. Relationship between some enzyme activity, sperm morphology and stallion semen quality. Lucr stiintifice Zooteh Biotehnol. 40:152-156.

Riyadhi, M, Arifiantini RI, Purwantara B. 2012. Korelasi morfologi abnormalitas primer spermatozoa terhadap umur pada beberapa bangsa sapi potong. Agroscientiae. 19:79-85.

Rizal M, Toelihere MR, Yusuf TL, Purwantara B, Situmorang P. 2003. Karakteristik penampilan reproduksi pejantan domba Garut. JITV. 8:134-140.

Sarastina, Susilawati T, Ciptadi G. 2012. Analisa beberapa parameter motilitas spermatozoa pada berbagai bangsa sapi menggunakan Computer Assisted Semen Analysis (Casa). J Ternak Trop. 6:1-12.

Sudarjat A. 2009. Kualitas semen segar pejantan domba Garut di Peternakan Ternak Domba Sehat Kampoeng Ternak Bogor. http://www.kampoengternak.or.id.

Sujoko H, Setiadi MA, Boediono A. 2009. Seleksi spermatozoa domba Garut dengan metode sentrifugasi Gradien Densitas Percoll. J Vet. 10:125-132.

Suryohudoyo P. 2000. Ilmu Kedokteran Molekuler. Cetakan Pertama. Jakarta (Indonesia): CV Sagung Seto. Hlm. 31-47.

Syarifuddin A, Desak NDIL, Wayan B. 2012. Efektivitas penambahan berbagai konsentrasi Glutathione terhadap daya hidup dan motilitas spermatozoa sapi Bali post thawing. Indonesia Medicus Veterinus. 173-185.

Toelihere. 1993a. Fisiologi reproduksi pada ternak. Cetakan keenam. Bandung (Indonesia): Angkasa. 
Toelihere. 1993b. Inseminasi Buatan pada Ternak. Cetakan keenam. Bandung (Indonesia): Angkasa.

Werdhany WI. 1999. Efektivitas penambahan $\alpha$-tokofrol di dalam pengencer tris dan susu skim terhadap kualitas semen kambing peranakan Etawah (Thesis). [Bogor (Indonesia)]: Institut Pertanian Bogor. 